\title{
PENGARUH CITRA MEREK TERHADAP KEPUTUSAN PEMBELIAN ULANG PRODUK HAWWA SKINCARE DI KABUPATEN BANDUNG
}

\author{
Dewi Rohaeti, Tiris Sudrartono
}

Fakultas Ekonomi dan Bisnis Politeknik Piksi Ganesha Bandung, Program Studi Manajemen Bisnis Email: dhewiizhee@gmail.com

\begin{abstract}
We can know that the cosmetic business is very mushrooming in Indonesia, one of which is in Bandung Regency. This research was conducted in one of the beauty clinics in Bandung district. The purpose of this study was to determine the effect of brand image and repurchase decisions at the clinic, the analytical method used in this study was a simple linear analysis and the data was then processed using the SPSS V.20 program. The sample used in this study as many as 93 respondents, are customers who make repeat purchases. The results of this study indicate that brand image is very influential to make repeat purchases at a time like this where there are many competitors who prioritize the brand.
\end{abstract}

Keywords:Brand Image, Repurchase decision

\begin{abstract}
Abstrak
Dapat kita ketahui bisnis kosmetik sangat menjamur di Indonesia salah satunya dikabupaten Bandung. Penelitian ini di lakukan di salah satu klinik kecantikan di kabupaten Bandung. Tujuan diadakannya penelitian ini ialah untuk mengetahui pengaruh citra merek dan keputusan pembelian ulang di klinik tersebut, metode analisis yang di gunakan dalam penelitian ini adalah anaisis linear sederhana dan data tersebut kemudian di olah menggunakan program SPSS V.20. Sampel yang digunakan dalam penelitian ini sebanyak 93 responden, merupakan pelanggan yang melakukan pembelian ulang. Adapun hasil penelitian ini menjukan bahwa citra merek sangatlah berpengaruh untuk melakukan pembelian ulang di saat kondisi seperti ini dimana banyaknya pesaing yang sangat mengedepankan merek.
\end{abstract}

Kata kunci: Citra Merek, keputusan pembelian ulang

\section{Pendahuluan}

Seperti yang kita ketahui bahwa produk Kecantikan sangatlah banyak peminatnya pada tahun 1950-an pada saat perekonomian masih sangat lemah pabrik kosmetik belum ada di indonesia. Kosmetik kosmetik yang ada, produk luar negri. Pembelajaran pun masih terbatas di kelas menengah-atas karena hanya barang langka dan mewah. Sementara itu, produk kosmetik dalam negeri belum muncul.

Begitu masuk orde baru pada tahun 1960-an pertumbuhan ekonomi meningkat di barengi kenaikan jumlah kelas menengah. Daya beli masyarakat meningkat produk produk dalam negri pun bermunculan. 
Kesadaran orang untuk merawat kulit meningkat. Dan pada saat itulah produk kosmetik dalam negeri pertama kali muncul yaitu viva kosmetik dan di susul oleh Martha Tilaar pada tahun 1970-an atau sekarang lebih di kenal dengan sari ayu martha tilaar.Sejak tahun itulah produk kosmetik mulai menjamur sampai saat ini bahkan banyak perusahaan yang menjual kosmetik wajah atau sekarang lebih di kenal sebagai skincare wajah, dengan harga yang relatif bisa di bilang terjangkau bagi semua kalangan.

Banyak bertebaran klinik di berbagai penjuru dunia yang menawarkan perawatan kecantikkan bahkan tidak segan mereka menawarkan prodak yang mengklaim bahwa prodak tersebut bisa cepat mencerahkan kulit wajah bagi yang memakainya.

Tidak hanya kulit wajah saja bahkan banyak perempuan yang menginginkan kulit tubuhnya cerah khusus nya di Indonesia dengan kulit kecoklatan dan sawo matang, ingin merubah warna kulit nya menjadi lebih cerah dan mereka tidak tanggung untuk mengeluarkan budget yang begitu cukup menguras kantong dan pasti nya tidak sedikit dari mereka rela mengambilresiko yang sangat mempengaruhi kesehatan.

Synnott (1993: 115116) mengatakan bahwa wajah adalah alasan mendasar sebuah kecantikan atau keburukan seseorang, dan semua alasan ini secara gamlang membuka diri dan peluang hidup kita. Wajah benarbenar melambangkan diri yang berbeda dari bagian diri dalam banyak hal. Seseorang dapat di identifikaasikan melalui wajahnya bukan bagian tubuh lainnya.

Kecantikan menjadi alasan nomor satu bagi mereka yang memiliki anggaran khusus untuk meningkatkan keinginan membeli skin care wajah atau melakukan perawatan tubuh di klinik kecantikan.

Hawwa skincare adalah salah satu merek skincare yang ada di indonesia khusus nya di kabupaten bandung, hawwa skincare berdiri sejak tahun 2010 silam, bisa juga di bilang produk ini belum begitu merajai industri kosmetik pada umumnya tapi tidak di ragukan lagi bahwa produk ini pun telah mempunyai customer yang sudah banyak juga skincare ini sudah menjual prodak nya sampai ke luar kota.

Di jaman sekarang skincare itu merupakan produk kecantikan yang wajib di miliki setiap individu tidak hanya kaum wanita tapi laki-laki pun ikut serta memakai produkskincare ini semata-mata untuk menunjang penampilan dan juga agar terlihat lebih segar jika kulit nya terawat.

Pada tahun 2019 akhir, pandemi covid19 atau lebih di kenal virus corona pun 
menyerang indonesia dan perekonomian mulai melemah karena banyak perusahaan yang membatasi interaksi sosial, barang barang yang di eksporpun mulai di batasi pengeluarannya. Dan indonesia pun mulai mengalami krisis perekonomian dengan banyak nya karyawan yang di PHK, kerja pun di lakukan di rumah, melakukan sosial distancing. Dan pada tahun 2020 hawwa skincare pun ikut terkena dampak perekonomian, dengan turun nya jumlah persentase pembelian produk kosmetik. Bisa di lihat di bawah dalam bentuk tabel dan grafik nya.

Di era modern seperti sekarang ini dan banyaknya jenis merek skincare yang bertebaran di pasaran dari mulai yang merek nya baru rilis sampe dengan merek terkenal di dunia. Daya beli masyarakat meningkat produkdalam negeri pertama kali muncul yaitu viva kosmetik dan di susul oleh Martha Tilaar pada tahun 1970-an. Sejak tahun itulah produk kosmetik mulai menjamur sampai saat ini. Keyakinan orang dulu mengenai kecantikan itu telah dikontruksi secara sosial, politik, maupunfinansial dalam kebudayaan yang mengekploitasi kemampuan perempuan.

Naomi Wolf bertutur mengenai kepercayaan kecantikan, kecantikan sungguh dengantradisi suatu daerah, wanita selalu ditempatkan sebagai makhluk yang di lihat dan dinilai oleh laki-laki. sehingga perempuan hanya memiliki 2 pilihan: memiliki pikiran atau memiliki kecantikan. Banyak bertebaran klinik di berbagai penjuru dunia yang menawarkan produk kecantikan bahkan tidak segan mereka menawarkan produk yang mengklaim produk tersebut bisa cepat mencerahkan kulit wajah bagi pemakai nya.

\section{Tabel 1.Data Pendapatan Produk di}

Hawwa Skincare

\begin{tabular}{|l|l|l|}
\hline \multicolumn{1}{|c|}{ BULAN } & $\begin{array}{l}\text { JUMLAH } \\
\text { PEMBELI }\end{array}$ & $\begin{array}{l}\text { PERSENTASE } \\
\text { NAIK TURUN }\end{array}$ \\
\hline JANUARI & 150 & $0,00 \%$ \\
\hline FEBRUARI & 127 & $-15,33 \%$ \\
\hline MARET & 130 & $2,36 \%$ \\
\hline APRIL & 103 & $-20,77 \%$ \\
\hline MEI & 102 & $-0,97 \%$ \\
\hline JUNI & 85 & $-16,67 \%$ \\
\hline JULI & 95 & $11,76 \%$ \\
\hline AGUSTUS & 89 & $-6,32 \%$ \\
\hline SEPTEMBER & 86 & $-3,37 \%$ \\
\hline OKTOBER & 75 & $-12,79 \%$ \\
\hline NOVEMBER & 73 & $-2,67 \%$ \\
\hline DESEMBER & 70 & $-4,11 \%$ \\
\hline
\end{tabular}

Sumber : Data pembelian Hawwa skincare 2020

Untuk lebih jelasnya mari kita lihat data grafik persentase naik turunnya pembelian produk hawwa skincare berikut ini : 


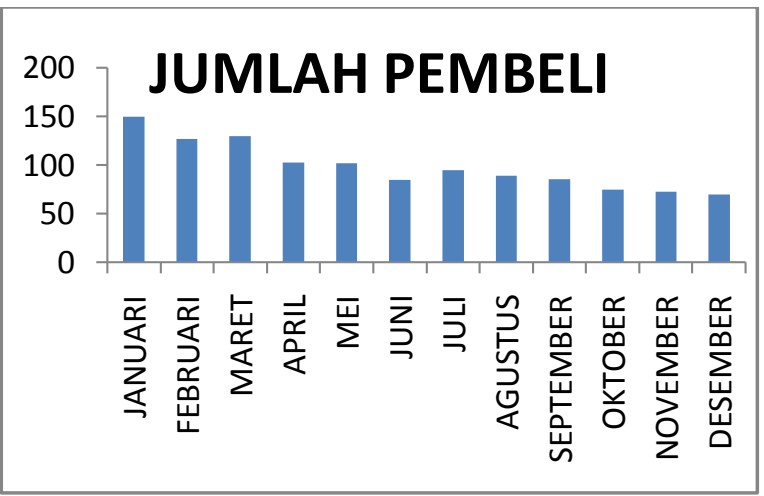

Sumber grafik pembelian skincare di Hawwa

Grafik 1. Pembelian Skincare Hawwa pada Tahun 2020

Pembelian di Hawwa skincare pada bulan juni mengalami penurunan pembelian menajidi 85 orang dengan persentase $16,67 \%$ dari bulan sebelumnya, lalu kebulan berikut nya pada bulan juli Hawwa skincare mulai ada kenaikan harga pembelian menjadi 95 orang orang dengan persentase sebesar $-11,76 \%$ lalu pada bulan agustus mengalami penurunan Kembali menjadi 89 orang dengan angka persentase menunjukan sebesar $-6,32 \%$ dari bulan sebelum nya, pada bulan oktober pun mengalami penuruna pembelian Kembali menjadi 75 orang dengan persentase penurunan pembelian sebesar $-12,79 \%$ dari bulan sebelum nya, lalu pada bulan November mengalami penurunan Kembali sebesar 73 orang angka ini menjukan penurunan yang sangat drastis dengan angka persentase sebesar-2,67\%. Desember menjadi bulan terakhir pada tahun 2020 yang jadi penentu bahwa pada bulan itu ekonomi Indonesia sedang mengalami penurunan akibat wabah pandemic covid-19 dan di bulan desember pun Hawwa skincare mengalami penurunan Kembali bahkan yang sangat drastis dan tidak dapat di bayangkan sebelumnya dengan jumlah pembelian 70 orang dengan besar persentase senilai $-4,11 \%$ jauh dari bulan bulan sebelum nya. Maka oleh sebab itu penelitian pun berfokus pada pengaruh citra merek dan keputusan pembelian ulang skincare Hawwa

\section{Tinjauan Pustaka}

Menurut Alma dan Saladin (2010), nama brand adalah nama, istilah, tanda, gambar atau rencana, atau campuran dari apa pun, yang diharapkan untuk mengenali tenaga kerja dan produk dari kumpulan pedagang dan untuk membedakan tenaga kerja dan produk tersebut. produk dari para pesaing .

Ada faktor-faktoryang mensugestikan mengenai gambaran sebuah produk, Schiffman \& Kanuk (2007) menjelaskan faktor-faktor yang membentuk brand image yaitu:

1) Kualitas, diidentikkan bersama sifat produk yang disajikan oleh pemilik produk yang menggunakan merek tertentu. 
2) Terpercaya/ dapat diharapkan. terkait melalui sentimen atau pertunjukan yang dibuat oleh individu tentang item yang dibakar .

3) Kegunaan atau kelebihan diidentifikasikan dengan kapasitas yang ditunjukkan oleh suatu barang yang dapat digunakan oleh pembeli .

4) Harga,untuk situasi ini mengidentifikasi dengan penggunaan tinggi atau jumlah minimal uang yang dihabiskan oleh pembeli untuk mengusulkan suatu barang, juga dapat mempengaruhi gambaran jangka panjang.

5) Gambaran merek yang sebenarnya, khususnya perspektif, pertunjukan, dan data yang diidentifikasi dengan merek seperti yang ditunjukkan oleh item tertentu.

Gambaran merek adalah gagasan asing tentang barang atau administrasi yang mengingat cara merek berusaha memenuhi kebutuhan mental atau sosial klien.

Jadi gambaran merek itu adalah pemahaman pembelanja tentang merek secara keseluruhan keseluruhan.

Seperti yang ditunjukkan oleh Kotler dan Keller (2009: 184) Pilihan pembelian adalah interaksi bergabung yang digunakan untuk mengkonsolidasikan informasi, menerapkan setidaknya dua praktik elektif dan memilih salah satunya. Keputusan pembeli adalah cara untuk menangani masalah penanganan dalam latihan manusia untuk membeli tenaga kerja dan produk untuk memenuhi kebutuhan dan kebutuhan mereka.

Ada 2 faktor yang terletak antara niat pembeli dan keputusan pembelian, yaitu :

1) Perilaku semakin kuat sikap negatiforang lain dengan pembeli semakin besar, pembeli akan mengubah keinginaan pembelian mereka. Situasi sebaliknya juga berlaku.

2) Faktor situasional yang tidak Terpikirkan sebelum nya,berakibat mmpu terjadi dan mengubah keinginanmembeli. Ini mungkin karena calon pembeli kehilangan pekerjaan, pembelian lain lebih mendesak, atau layanan toko menghalangi pembelian..

\section{Metode Penelitian}

Menurut Resseffendi (2010:33), pemeriksaan ilustratif kuantitatif adalah penelitian yang memanfaatkan persepsi, pertemuan atau survei tentang keadaan pasang surut yang sesuai dengan subjek yang kita telusuri. Kami mengumpulkan informasi melalui survei, dan sebagainya untuk menguji hipotensi atau untuk menjawab pertanyaan. Melalui pemeriksaan 
grafis ini, spesialis akan mengklarifikasi apa yang sebenarnya terjadi dalam keadaan yang sedang diteliti.

Strategi ilmiah yang digunakan adalah pemeriksaan langsung secara langsung. dengan contoh 93 responden dan selanjutnya disusun dan ditangani menggunakan SPSS v.20.

hipotesis yang diajukan dalam ulasan ini adalah bahwa kualitas bantuan memiliki dampak positif dan besar pada minat pembelian kembali di antara klien item perawatan kulit Hawwa.

Ha = citra merek berpengaruh pada minat beli ulang

Dengan kerangka berpikir:

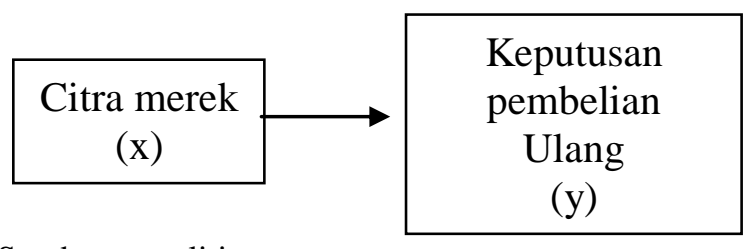

Sumber: peneliti

Gambar 1. Kerangka berfikir

\section{Hasil Penelitian dan Pembahasan}

\subsection{Hasil Penelitian}

Berikut merupakan refresentasi tentang karakteristik responden.

Uji validitas dengan jumlah responden sebanyak 79 orang.

\section{Citra merek $(\mathbf{X})$}

Berikut hasil dari validitas $\mathrm{X}$ yaitu :
Tabel 2.Uji Validitas (X)

Item-Total Statistics

\begin{tabular}{|l|c|c|c|c|c|}
\hline & $\begin{array}{c}\text { Scale } \\
\text { Mean if } \\
\text { Item } \\
\text { Deleted }\end{array}$ & $\begin{array}{c}\text { Scale } \\
\text { Variance } \\
\text { if Item } \\
\text { Deleted }\end{array}$ & $\begin{array}{c}\text { Corrected } \\
\text { Item-Total } \\
\text { Correlation }\end{array}$ & $\begin{array}{c}\text { Squared } \\
\text { Multiple } \\
\text { Correlation }\end{array}$ & $\begin{array}{c}\text { Cronbach } \\
\text { s Alpha if } \\
\text { Item } \\
\text { Deleted }\end{array}$ \\
\hline X1 & 32.57 & 87.335 & .488 & .361 & .965 \\
X2 & 32.18 & 79.108 & .883 & .857 & .949 \\
X3 & 32.20 & 79.990 & .864 & .815 & .950 \\
X4 & 32.24 & 80.096 & .870 & .787 & .950 \\
X5 & 32.49 & 82.535 & .804 & .710 & .953 \\
X6 & 32.31 & 79.152 & .889 & .925 & .949 \\
X7 & 32.31 & 79.282 & .890 & .928 & .949 \\
X8 & 32.31 & 80.239 & .855 & .799 & .951 \\
X9 & 32.41 & 81.962 & .841 & .748 & .951 \\
X10 & 32.10 & 82.067 & .747 & .629 & .955 \\
\hline
\end{tabular}

Sumber : Data yang diolah penulis, 2021

Tabel 3. Uji Reliabilitas $X$

\begin{tabular}{|l|l|}
\hline Cronbach's Alpha & N of Items \\
\hline 0,957 & 10 \\
\hline
\end{tabular}

Sumber : Data yang diolah penulis,2021

Jika koefisien reliabilitas > 0,60 maka dinyatakan variabel layak digunakan untuk penilitian selanjutnya. Data ditampilkan pada dua buah tabel atas dinyatakan layak.

\section{Keputusan pembelian (y)}

Tabel 4.Uji validitas (Y)

Item-Total Statistics

\begin{tabular}{|c|c|c|c|c|c|}
\hline & $\begin{array}{c}\text { Scale Mean } \\
\text { if Item } \\
\text { Deleted }\end{array}$ & $\begin{array}{c}\text { Scale } \\
\text { Variance if } \\
\text { Item } \\
\text { Deleted }\end{array}$ & $\begin{array}{c}\text { Corrected } \\
\text { Item-Total } \\
\text { Correlation }\end{array}$ & $\begin{array}{c}\text { Squared } \\
\text { Multiple } \\
\text { Correlation }\end{array}$ & $\begin{array}{c}\text { Cronbach's } \\
\text { Alpha if } \\
\text { Item } \\
\text { Deleted }\end{array}$ \\
\hline Y1 & 25.18 & 23.955 & .477 & .677 & .750 \\
Y2 & 25.31 & 24.521 & .545 & .731 & .737 \\
Y3 & 25.63 & 24.756 & .529 & .709 & .740 \\
Y4 & 25.70 & 25.365 & .465 & .719 & .751 \\
Y5 & 25.48 & 25.318 & .464 & .592 & .751 \\
Y6 & 25.59 & 26.049 & .419 & .515 & .758 \\
Y7 & 25.43 & 25.248 & .469 & .792 & .750 \\
Y8 & 25.34 & 26.032 & .432 & .754 & .756 \\
\hline
\end{tabular}

Sumber : Data yang diolah penulis,2021 
Tabel 5. Uji Reliabilitas Y

Reliability Statistic

\begin{tabular}{|l|l|}
\hline Cronbach's Alpha & \multicolumn{1}{c|}{ N of Items } \\
\hline 0,774 & 8 \\
\hline
\end{tabular}

Sumber : Data yang diolah penulis,2021

Maka hasil dari uji reliabilitas variabel Y atau (Minat Beli Ulang) dengan seluruh item yang diajukan memiliki rata-rata 0,774 > 0,6 dan dikatakan Andal atau Reliabel.

\section{Tabel 6.Kolmogorov-Smirnov Test}

One-Sample Kolmogorov-Smirnov Test

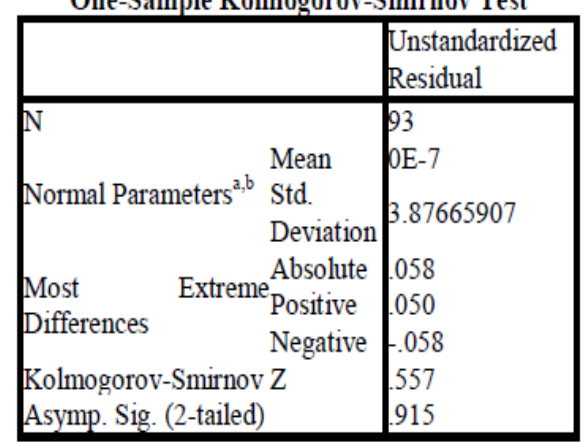

a. Test distribution is Normal.

b. Calculated from data.

Sumber : Data yang diolah penulis, 2021

Berdasarkan tabel output uji kolmogrov smirnov di atas, didapatkan nilai signifikasi dari uji normalitas sebesar 0,915 dimana hasil tersebut lebih besar dari 0,05, sehingga dapat disimpulkan bahwa uji test normalitas pada penelitian ini terdistribusi normal.

Tabel 7.Analisis Regresi Linear Sederhana

\begin{tabular}{|l|r|r|c|r|r|}
\hline Model & \multicolumn{2}{|c|}{$\begin{array}{c}\text { Unstandardized } \\
\text { Coefficients }\end{array}$} & $\begin{array}{c}\text { Standardized } \\
\text { Coefficients }\end{array}$ & T & Sig. \\
\cline { 2 - 6 } & \multicolumn{1}{|c|}{$\mathrm{B}$} & $\begin{array}{c}\text { Std. } \\
\text { Error }\end{array}$ & Beta & & \\
\hline $\begin{array}{c}\text { (Constant) } \\
1 \text { Citra } \\
\text { Merek }\end{array}$ & 14.362 & 1.516 & & 9.475 & .000 \\
\hline
\end{tabular}

Dependent Variable: Minat Beli Ulang
Sumber: data yang diolah penulis, 2021

Berdasarkan tabel diatas dapat diketahui bahwa konstanta sebesar 14.362, angka ini dapat diartikan bahwa bahwa jika citra merek sama dengan NOL, maka nilai konsisten kepuasan nasabah adalah 14.362, sedangkan angka koefisien dari output diatas adalah sebesar 0,410. Angka tersebut mengandung arti bahwa setiap penambahan $1 \%$ citra merek, maka Tingkat minat beli ulang akan meningkat sebesar 0,410 dan berpengaruh positif terhadap Minat Beli Ulang . Jika dibandingkan dengan nilai Sig dengan nilai probobalitas 0,05 dari hasil output tabel 8 yaitu berpengaruh signifikan Citra Merek dengan Tingkat keinginan membeli Ulang dengan hasil 0,000 0,05.

\section{Tabel 8.Uji t (Uji Parsial)}

Coefficients $^{\mathrm{a}}$
\begin{tabular}{|l|l|l|l|l|l|}
\hline Model & $\begin{array}{l}\text { Unstandardized } \\
\text { Coefficients }\end{array}$ & $\begin{array}{l}\text { Standardized } \\
\text { Coefficients }\end{array}$ & & Sig. \\
& $\mathrm{B}$ & $\begin{array}{l}\text { Std. } \\
\text { Error }\end{array}$ & Beta & & \\
& & & & \\
\hline 1 (Constant) & 14.362 & 1.516 & & 9.475 & 000 \\
Citra Merek & 410 & 041 & 727 & 10.086 & 000 \\
\hline
\end{tabular}

a. Dependent Variable: Minat Beli Ulang

Sumber: Data yang diolah penulis, 2021

Berdasarkan hasil output SPSS V.20 atau tabel 8 dapat disimpulkan bahwa nilai $t_{\text {hitung }}$ adalah sebesar $10,086>t_{\text {tabel }} 1,660$ dengan tingkat signifikan $0,00<0,05$ maka $\mathrm{H}_{\mathrm{o}}$ ditolak dan $\mathrm{H}_{1}$ diterima yang berarti bahwa Variabel X (Citra Merek) 
berpengaruh positif signifikan terhadap

Variabel Y (Minat Beli Ulang).

Tabel 9.Model Koefisien Determinasi

Model Summary

\begin{tabular}{|c|c|c|c|c|}
\hline $\begin{array}{c}\text { Mode } \\
1\end{array}$ & $\mathrm{R}$ & R Square & $\begin{array}{c}\text { Adjusted } \\
\text { R Square }\end{array}$ & $\begin{array}{c}\text { Std. Error of } \\
\text { the Estimate }\end{array}$ \\
\hline 1 & $.727^{\mathrm{a}}$ & .528 & .523 & 3.898 \\
\hline
\end{tabular}

a. Predictors: (Constant), Kualitas Pelayanan

b. Dependent Variable: Minat Beli

Sumber : Data yang diolah penulis, 2021

Diperoleh informasi bahwa nilai korelasi ( $r$ ) yang diperoleh antara Cita Merek dengan Minat Beli Ulang adalah sebesar 0,727. Nilai 0,727 Menurut Sugiyono (2013-214) berada pada Interval 0,70-1,000 masuk kedalam kategori yang sangat kuat dengan arah positif . Sehingga bisa dijelaskan bahwa terdapat hubungan yang positif dan kuat antara Citra Merek dengan Minat Beli Ulang, yang dimana semakin berkualitasnya Citra Merek pada produk maka akan diikuti dengan semakin Tinggi Minat Beli Ulang, layanan yang diberikan oleh hawwa skincare.

Dari grafik hasil output SPSS di atas juga, disimpulkan bahwa nilai koefisien determinasi atau $R$ square sebesar 0,528 atau 52,8\%. Hal ini menunjukan bahwa variabel Citra Merek pada Produk Hawwa skincare rancaekek mampu dipengaruhi oleh Minat beli ulang sebesar 52,8\% (52,8\%).

\subsection{Pembahasan}

Dari hasil hipotesis pencarian data, didapatkan hasil secara persial ternyata Brand image berpengaruh kepada keinginan membeli ulang sebuah produk. adanya peluang yang dapat mengungkapkan bahwa hasil pengujian valid. sekelompok pembeli memandang bahwa citra merek sangat berpengaruh terhadap minat beli ulang, Karena dari penelitian yang saya lakukan bahwa citra merek sudah memiliki keunggulan di pasaran karena berdasarkan hasil data statistik menunjukan nilai sig 915 $>0,06$. Karena citra merek adalah patokan utama bagi sekelompok pembeli untuk membeli ulang produk nya. Oleh karena itu pelanggan menganggap penting bahwa citra merek mempengaruh sebuah pembelian ulang. Mengacu kepada judul yang sama maka diperoleh beberapa hasil riset yang menguatkan hasil ini yaitu Nugroho (2018), kustianti (2019), dan Magang (2020). sedangkan Hutapea dkk (2021) menyatakan hanya secara serempak dengan kualitas produk citra merek berpengaruh, namun jika dilakukan secara parsial pengaruhnya tidak signifikan.

Aaker \& Biel (1993) berpendapat bahwa brand image yaitu penilaian pembeli terhadap merek di suatu pasar. Kreasi dapat dibuat berdasarkan pengalaman pribadi atau 
mendengar sebuah kelebihan dari orang lain atau media. Jadi dari hasil penelitian bahwa citra merek merupakan penentu dalam keputusan pembelian, karena citra merek dapat tercipta dari pengalaman pribadi sang pembeli.

Selanjutnya Schiffman \& Kanuk (2007), berpendapat bahwa citra merek adalah seperangkat asosiasi terhadap suatu merek yang tersimpan di benak atau cinderamata konsumen. Karena jika merek itu memberikan kesan positi bagian pemakai/ pengguna maka merek itu akan di kenang.

Walaupun sebagaian orang mengatakan bahwa harga menentukan kualitas tapi menurut sebagian orang lagi mengatakan bahwa merek menentukan harga dan kualitas sebuah produk/ barang. Dikutip dari pendapat Hasan (2013:215-217) dengan merek yang dikenal luas oleh masyarakat memudahkan pemakai barang/jasa untuk mengevaluasi, menakar serta melaksanakan keputusan pembelian yang diperoleh melalui unsur-unsur nilai yang terkait dengan kinerja produk, harga, serta pendistribusiannya.

\section{Kesimpulan dan Saran}

\subsection{Kesimpulan:}

Berdasakan hasil pengkajian sebelum nya diperoleh ketentuan seperti berikut :
Secara keseluruhan bahwa brand image sangat mempengaruhi Tentang keinginan membeli ulang, ternyata gambaran merek adalah alasan krusial yang mempengaruhi daya fikir atau keinginan membeli ulang produk Hawwa Skin Care.

Kualitas produk mempengaruh tujuan pembelian kembali konsumen di Hawwa Skin Care, yang berarti kualitas sebuah produk adalah faktor ke 2 yang utama selain Brand image yang mempengaruhi keinginan membeli ulang produk Hawwa Skin Care.

\subsection{Saran}

Saran yang di sampaikan penulis dalam penelitiannya adalah :

a. Hawwa skin care butuh peningkatan brand image yang efisien supaya dapat bersaing dengan pesaing lainnya dalam masalah brand image, lebih berinovasi membuat ragam baru atau memperbaiki produk yang sudah ada selain menjadi prioritas utama untukpembeli dalam menentuka hasrat membeli ulang sebuah produk.

b. Hawwa skin care di harapkan mampu menaikan level kualitas produknya supaya mampu bersaing dengan produk lain dalam masalah mutu sebuah produk. 


\section{DAFTAR PUSTAKA}

Aaker, D. A., \& Biel, A. L. (1993). Brand equity and advertising: An overview. Hillsdale, NJ: Lawrence Erlbaum Associates.

Alma, B., \& Saladin, D. (2010). Manajemen Pemasaran: Ringkasan Praktis, Teori, Aplikasi, dan Tanya Jawab. Bandung: CV Linda Karya.

Dwi Desy Ninik Kustianti.(2019). Pengaruh Citra Merek dan Harga Terhadap Keputusan

Pembelian Ulang Kartu Seluler Telkomsel. Psikoborneo, Vol 7, No 1, 2019:83-92.

Hasan, Ali. (2013). Marketing dan KasusKasus Pilihan. Yogyakarta: CAPS (Center For Academic Publishing Service).

Hutapea, M., awaludin, A., Bangun, rosniwaty, \& Yunita, M. (2021). Pengaruh Brand Image Dan Kualitas Produk Terhadap Keputusan Pembelian Underware Gt Man Pada Pt Ricky Putra Globalindo Tbk. VALUE, 2(1), 11-21. https://doi.org/10.36490/value.v2i1.1 $\underline{79}$

Kotler, P., \& Keller, K. L. (2009). Manajemen Pemasaran (13th ed.; B. Sabran, ed.). Jakarta: Erlangga.

Magang, Ronaldo Nasario.(2020). Pengaruh Citra Merek, Kualitas Produk, Dan Harga Terhadap Keputusan Pembelian Ulang Handphone Vivo Di Kabupaten Sleman. Skripsi. Universitas Pembangunan Nasional "Veteran" Yogyakarta.
Nugroho, Arya (2018) Pengaruh Kualitas Produk, Citra Merek, Dan Kepuasan Konsumen Terhadap Keputusan Pembelian Ulang (Studi Pada Konsumen Frestea Di Kotamadya Yogyakarta). S1 thesis, Fakultas Ekonomi.

Resseffendi. (2010). Metode Penelitian. NASPA Journal, 33, 26-36.

Schiffman, L. ., \& Kanuk, L. L. (2007). Perilaku Konsumen. Jakarta: Indeks Gramedia.

Synnott, A. (1993). The Body Social: Symbolism, Self and Society. London $\&$ New York: Routledge. 